\title{
A TRADUÇÃO DE CASA-GRANDE E SENZALA EM FRANCÊS*
}

\section{Gloria Carneiro do Amaral**}

Resumo: O sociólogo Roger Bastide, fascinado pela obra de Gilberto Freyre, fez uma tradução de Casa-grande e Senzala para o francês em 1952. O presente artigo propõe-se a examinar o resultado deste trabalho e certas opções do tradutor francês, a braços com a árdua tarefa de passar para sua língua esse texto tão particular e que lida com traços tão típicos da cultura brasileira.

Palavras-chave: Tradução. Gilberto Freyre. Bastide.

\section{A tradução de Casa-grande e Senzala: Circunstâncias}

$\mathbf{A}$ fascinação de Roger Bastide pela obra de Gilberto Freyre levou-o a fazer a única tradução de sua carreira, a de Casa-grande e Senzala para o francês, em 1952, reeditada pela Gallimard em 1974, confirmando o interesse do público francês pela obra do sociólogo brasileiro.

Como foi recebida a tradução?

A edição conta com um prefácio de Lucien Febvre, para quem a tradução parece "atenta". Wilson Martins (1954, p. 338-340), em resenha para a revista Anhembi, considera-a "um admirável sucesso científico e literário", "feliz e fiel", conseguindo transpor para uma língua, na sua opinião, tão lógica quanto o francês, o estilo muito pessoal do sociólogo brasileiro. O que não teria se dado sem dificuldades, segundo lhe confidenciara o próprio tradutor em conversa informal.

Este texto figurava como anexo na minha tese de livre-docência Navette literária França-Brasil: a crítica de Roger Bastide. Ao publicá-la, não o inclui porque achei-o um estudo paralelo ao tema central do trabalho. Apresentei-o sob forma de comunicação em Florianópolis, 24 de setembro de 2013. Trata-se aqui de sua primeira publicação.

** Universidade Presbiteriana Mackenzie (UPM) - São Paulo - SP - Brasil. E-mail: gloria.amaral@mackenzie.br 
Não há registros do tempo que Bastide teria consagrado à tradução. O seu ritmo habitualmente intenso de trabalho estaria provavelmente passando por um momento especialmente agitado: entre 1951 e 1954, Bastide deu aulas no Brasil e na França, pois começava a ocupar um lugar de directeur d'études, que lhe tinha sido proposto por Lucien Febvre, na Ecole Pratique des Hautes Etudes, VIe. section (EPHE). Foi um período de readaptação aos meios acadêmicos e intelectuais franceses, dos quais tinha ficado à margem por cerca de 12 anos, tempo em que permaneceu no Brasil. Em 1952, fez também uma viagem ao Brasil central em função de uma pesquisa de campo para um estudo das relações raciais que estava desenvolvendo para a Unesco, com a colaboração de Pierre Verger.

$\mathrm{Na}$ "Carta aberta a Guerreiro Ramos", encontramos de forma sucinta e clara a sua posição em relação ao livro de Gilberto Freyre e como sua tradução foi recebida na França, na opinião do próprio tradutor:

É aqui que eu colocaria Gilberto Freyre, que V. quer por na categoria dos estrangeiros preocupados apenas com o pitoresco. Gilberto Freyre tentou, ao contrário, criar, e é o que o distingue de Oliveira Viana, uma sociologia sem a priori de "importação". E a prova está em que não sabemos como classifica-lo, se entre os historiadores, entre os sociólogos, na geografia humana. É que para estudar as relações inter-humanas no Brasil, ele foi obrigado a criar um método próprio, uma espécie de sociologia proustiana; essa novidade foi bem recebida na França. Se V. ler as críticas da tradução de Casa-Grande e Senzala verá que o que impressionou os franceses náo foi bem o pitoresco, mas como disse Les Temps Modernes, ofato de ter o autor inventado uma sociologia humanista. Com ele, é a ciência brasileira que se apresenta como modelo a seguir aos europeus (BASTIDE, 1953, p. 524).

\section{SOBRE A TRADUÇÃo doS DOIS ElEMENTOS COMPONENTES DO TÍtUlo: CASA- -GRANDE E SENZALA}

O prefaciador da tradução, Lucien Febvre, tem ressalvas ao título Maîtres et esclaves que lhe parece empobrecedor e "bon pour roman russe des années 1900"1. Roland Barthes acha o título "presque trop hegelien pour un contenu somme toute matérialiste"2.

Efetivamente, a tradução do título é empobrecedora. Implica a perda do elemento espacial, de importante carga sociológica, além da alteração de duas expressões muito significativas para a cultura brasileira. No entanto, entende-se a necessidade de, no título em francês, substituí-las, em face da impossibilidade de uma tradução literal e pela inexistência dos termos na cultura francesa.

Embora em nenhum momento de sua tradução indique o componente espacial do título, Bastide tinha dele plena consciência, pois numa resenha de Ordem e Progresso (1959) observa:

"bom para um romance russo dos anos 1900" (FREYRE, 1974, p. 11). Todas as referências à tradução em francês são de Freyre (1974) e têm as páginas indicadas entre parênteses.

2 "hegeliano demais para um conteúdo fundamentalmente muito materialista" (BARTHES, 2002, p. 253). 
Mais tout de suite, ces titres nous suggèrent une remarque. G. Freyre partait toujours, pour expliquer la famille, de la maison où elle habitait, et ses transformations étaient toujours liées à des modifications dans la nature des résidences (BASTIDE, 1959, p. 177) ${ }^{3}$.

Parece-me mais grave a alteração - sobretudo pela possibilidade de uma tradução literal em francês - do subtítulo que especifica a matéria em estudo na obra: "formação da família brasileira sob o regime da economia patriarcal", para um outro que generaliza demais a questão, "la formation de la société brésilienne".

No corpo do texto, Bastide conservou a expressão "senzala", que figura no glossário, explicada como uma palavra de origem bantu significando moradia. No entanto, o tradutor não indica que a expressão, no original, integra o título da obra. E "casa-grande" foi traduzida por "maison de maîtres". De uma forma geral, é assim que encontramos o par do título: "maison de maîtres" e senzala.

Considerando-se a totalidade do texto, as duas expressões do título sofreram tratamentos diversos:

Em geral, encontramos a tradução citada: "maison des maîtres" e senzala: "[...] as verminoses exerceram a sua maior ação devastadora só depois do descalabro da Abolição, estendida com igual intensidade aos negros e pardos já agora desamparados da assistência patriarcal das casas-grandes e privados do regime alimentar das senzalas" (FREYRE, 1992, p. 46) ${ }^{4}$. "[...] l'assistance patriarcale des 'maisons des maîtres' et qui étaient privés du régime alimentaire des senzalas" (p. 84).

Falando da sífilis, o autor considera-a o grande mal dos dois espaços: "Da ação da sífilis já não se poderá dizer o mesmo: que esta foi a doença por excelência das casas-grandes e das senzalas" (p. 47). "On ne peut en dire autant de la syphilis; ce fut le principal mal des 'maisons des maîtres' et des senzalas” (p. 85).

Ainda um outro exemplo: "No Brasil, a catedral ou a igreja mais poderosa que o próprio rei seria substituída pela casa-grande do engenho" (p. 195) "[...] sera remplacée par la maison de maître du moulin" (p. 186).

Encontramos outras traduções: "É ilusão supor-se a sociedade colonial, na sua maioria, uma sociedade de gente bem-alimentada. Quanto à quantidade, eram em geral os extremos: os brancos das casas-grandes e os negros das senzalas" (p. 33). "Quant à la quantité, elle n'était suffisante qu'aux deux extrêmes de l'échelle sociale, chez les seigneurs et chez les nègres" (p. 65).

Ora, a mesma afirmativa é assumidamente repetida pouco depois e traduzida de forma um pouco diferente: "Melhor alimentados, repetimos, eram na sociedade escravocrata os extremos: os brancos das casas-grandes e os negros das senzalas" (p. 34). "Ne craignons pas de le répéter, ceux qui étaient les mieux alimentés dans cette société esclavagiste, c'étaient les deux extrêmes: les seigneurs blancs et les nègres" (p. 67).

Ou simplesmente omite-se uma das expressões em trechos em que elas seriam fundamentais: "Por outro lado houve mulequinhos da senzala criados nas casas-grandes com os mesmos afagos e resguardos dos meninos brancos"

\footnotetext{
3 "Mas de imediato, estes títulos nos sugerem uma observação. G. Freyre partia sempre, para explicar a família, da casa em que habitava e suas transformações estavam sempre ligadas a modificações na natureza das residências".

4 Todas as citações adiante são desta edição de Freyre (1992), cujas páginas são indicadas entre parênteses.
} 
(p. 374). "Il y eut par ailleurs de petits mulâtres [----] élévés [----] avec les mêmes cajoleries et cet excès de précautions des petits blancs" (p. 365).

Omitir a oposição social nessa observação é aliviá-la de seu sentido fundamental: não se trata de qualquer mulato sendo levado para a casa-grande, mas de um escravo da senzala e com as consequências sociais que de tal atitude poderiam advir e bem conhecidas nesse contexto social. O que, aliás, é observado logo a seguir: "Cousa, já se vê, de iaiás solteironas, ou senhoras maninhas, que não tendo filho para criar deram para criar muleque ou mulatinho. E às vezes com um exagero ridículo de dengos" (p. 374). "Affaire, on les comprend, de vieilles filles ou de femmes stériles qui, n'ayant pas d'enfant à éléver, adoptaient un négrillon ou un petit mulâtre" (p. 365). Na tradução, omitem-se "iaiás" e "maninha", o que, como em muitos outros momentos, causa a perda de elementos de particular sabor, mas parece-me que o tradutor via-se a braços com expressões inexistentes na língua de chegada.

Ou ainda uma terceira mudança, que me parece demasiadamente arbitrária: "Mesmo a lingua falada conservou-se por algum tempo dividida em dois: uma, das casas-grandes; outra, das senzalas" (p. 333). "La langue parlé resta divisée en deux, celle de maisons de maîtres, celle des masures d'esclaves" (p. 319).

Essa oposição se repete igualmene traduzida em vários outros trechos, cujas páginas indico: p. 334/321; p. 351/338. Retomo aqui apenas um exemplo: "Doenças africanas seguiram-nos até o Brasil, devastando-os nas senzalas".

Em se tratando de uma referência às doenças africanas, nosso tradutor compadecido não resiste a introduzir um adjetivo inexistente em português: "Les maladies africaines les suivirent jusqu'au Brésil, les décimant dans leurs masures misérables" (grifo meu).

Cheguei a pensar que, por inexplicáveis razões, o tradutor mudara de ideia. Mas não: pode retomar a palavra senzala (p. 357/345) ou num mesmo parágrafo empregar as duas traduções: senzala/ masures d'esclaves (p. 357/345) (p. 362/350).

Ou traduzir senzala por uma explicação: "habitation d'esclaves" (p. 352/339).

Às vezes, a tradução pode conduzir a outras interpretações. Referindo-se ao ensino da lingua portuguesa, Freyre fala das "salas de aula das casas-grandes" contra a "corrupção das senzalas"(p. 334); o que resultou numa tradução de sentido bastante dúbio: "les salles de classe des maisons de maître" e "l'action corruptrice des noirs" (p. 320); a tradução passa a fazer incidir a corrupção sobre as pessoas.

Eventualmente as duas expressões são amalgamadas: "maisons de maîtres et d'esclaves" (p. 327), podendo ser omitidas em trechos em que as expressões têm seu peso significativo e cujas páginas indico igualmante: p. 352/340; p. 354/342; p. $374 / 36$.

Em alguns trechos, a omissão da palavra, aliada a outras de tradução precária pode implicar uma perda quase total do contexto social que estava implícito na descrição em português: "furor de don-juan das senzalas desadorado atrás das negras e mulecas" (p. 190); "en une fureur de Don Juan de servantes, impatient de négresses et de jeunes bonnes" (p. 181).

Essa arbitrariedade da tradução, que podemos, sem muito receio, considerar uma falta de critério, parece especialmente grave, pois está no cerne de um aspecto fundamental da obra. 
Podemos agregar a essas observações sobre as palavras do título a tradução de engenho, que não aparece no glossário e foi traduzido por "moulin". Ora, engenho é uma palavra brasileira que designa a moenda da cana-de-açúcar; e moinho é destinado a moer cereais. E na cultura brasileira há um contexto sociológico ligado ao engenho. É uma das poucas ressalvas de Wilson Martins (1954, p. 339):

Mas, no caso dos engenhos, por exemplo, cujo nome é quase uma palavra técnica, eu me pergunto se a sua tradução pura e simples em "moulins" dará uma idéia exata da coisa, e se não seria preferível conservá-lo na forma portuguesa, esclarecida sua significação em uma nota de rodapé.

Acredito que caiba a seguinte pergunta: até que ponto esse estrangeiro tão empenhado em conhecer a vida e a cultura brasileiras, que via com tão bons olhos o nosso país, entendia com maior profundidade a linguagem familiar brasileira.

\section{RECURSOS UTILIZADOS NA TRADUÇÃo DO LÉXICO REGIONAL E DOS NOMES PRÓPRIOS}

O primeiro e mais evidente problema de uma tradução de Casa-grande e Senzala é o abundante léxico regional, decorrente do próprio assunto abordado. Problema resolvido, em parte, de forma relativamente simples pelo tradutor: organizou um amplo glossário, com explicações sucintas e precisas. Solução em vários momentos eficiente; no entanto, não há notas de tradutor, o que, no caso, poderia ser de grande utilidade. Em se tratando de uma obra que gira em torno de um universo cultural tão particular e específico, parece-me evidente que se poderia lançar mão de um desses recursos, sem que isso implicasse prejuízo do nivel e da qualidade do trabalho de tradução; ao contrário. Mas, num ou noutro caso, seria necessário adotar critérios e segui-los e isso nem sempre acontece. Podemos observar soluções arbitrárias no glossário.

Em geral, as palavras são conservadas em português. No entanto, observa-se em algumas um afrancesamento da forma, cujo critério não está explicado e parece-me aleatório. Por exemplo, sertão, que aparece grafada para inserir-se no sistema fonético francês: sertan. O glossário diz tratar-se do interior do país, pouco povoado e quase selvagem, podendo aproximar-se de "brousse" e "bled". Atualmente, dicionários franceses como Petit Larrousse e Petit Robert trazem a palavra com sua grafia portuguesa e uma explicação que corresponde à dos nossos dicionários: "zone peu peuplée et semi-aride du Nordeste brésilien où domine l'élévage extensif". ${ }^{5}$

Por vezes, o tradutor se esquiva à dificuldade, lançando mão de uma construção sintática que o desembaraça do uso da palavra regional. Numa sucessão de parágrafos, Freyre refere-se às contribuições da mulher indígena à cultura brasileira, utilizando expressões diferentes: "a mulher gentia", "ela nos deu ainda a rede", "da cunhã é que nos veio o melhor da cultura indigena". "Antes de salientarmos a contribuição da cunhã" (p. 94) Evitando a palavra de origem tupi, o tradutor recorreu ao uso do demonstrativo: "ce rôle" para "a contribuição da cunhã". A substituição que não é grave, mas resulta num texto de chegada menos saboroso e mais padronizado; o que acontece mais de uma vez: "há mui-

\footnotetext{
5 "zona pouco povoada e semi-árida do Nordeste brasileiro onde domina a criação extensiva".
} 
ta gente de jenipapo ou de mancha mongólica no Brasil" (p. 283) reduziu-se simplesmente a "pas mal de gens ont la tache mongolique au Brésil" (p. 261).

Várias palavras tiveram a vogal final substituida por um "e". Assim as encontramos no corpo do texto e no glossário: cabocle, sertaneje, sertaniste. Por que essa mudança? Dificil de se entender, por que a alteração não se conserva nem se considerarmos um mesmo campo semântico: por que "ante" se conserva capivara, cotia e paca? Além disso, temos em francês as palavras tapir e cabiai ou capybara, todas dicionarizadas, com indicação de sua origem tupi.

Nomes das árvores típicas e inexistentes na flora europeia foram traduzidos com facilidade por acajous e araçaiers. A primeira é dicionarizada como palavra de origem portuguesa, designando a árvore, a madeira e a cor; a segunda, provavelmente é da lavra de Bastide. Constam as duas do glossário.

O nosso tradutor parece ter um princípio criativo bastante particular, talvez relacionado à sua pronúncia do português que - dizem os depoimentos mais idôneos - era muito particular. O que mais explicaria a criação de "modignes" para modinhas (p. 327) ou o afrancesamento da palavra "fazendaire"?

Jorge Amado, num texto sobre a visita de Bastide aos candomblés baianos, se pergunta:

Lembro-me da surpreendente conversa entre ele e a mãe Gomeia, que se desenrolou num dialeto novo, formado de francês e de nagô, onde despontava de quando em quando alguma rara palavra em português, como um presente para nós. Como se entenderam o sociólogo francês e a mãe de santo baiana? Até hoje não sei; para mim é um mistério maior que o da Santissima Trindade!

Esse mesmo tratamento arbitrário aparece também com relação a nomes próprios ou geográficos. Aliás, Wilson Martins (1954) reclamava já uma padronização nas transcrições de nomes próprios, ora em francês, ora em português.

"do Maranhão ao Rio Grande do Sul, e em Minas Gerais" (p. 283)

“du Maragnan à Rio Grande do Sul et dans l'état de Minas Gerais” (p. 261).

Conheceria Bastide o livro de Claude d'Abbeville de 1614, Histoire de la mission des pères capucines en l'isle de Maragnan et toutes circunvoisines, citado por Paulo Prado em Retrato do Brasil? Ou teria adotado o mesmo princípio fonético utilizado para modinha?

A sucessão de nomes que Freyre apresenta como sendo de negros: Benedito, Bento, Cosme, Damião, Romão, Esperança, Felicidade, Luzia (p. 453) tornou-se Benedicto, Benoît, Cosme, Damien, Romain, Espérance, Félicité, Lucie (p. 428). Mas, na página anterior, Francisco Gomes Brandão e José Antonio Gonçalves de Melo conservaram seus prenomes.

Essa mistura de línguas no tratamento dos nomes próprios pode também ser observada no seu livro sobre as religiões africanas no Brasil: Domingos George le Vieux, Jean Correia dos Santos, Sebastien Monteiro de Vide, a cidade de Saint-Jean d'El Rey, ao lado de Luis Gonzaga das Virgens, Francisco Prado de Mello.

Às vezes, a tradução resulta até em perda de informação sociológica, fundamental no texto em questão. Referindo-se às relações de cumplicidade entre a casa-grande e a senzala, temos a seguinte sequência: "aliança da ama-negra 
com o menino branco, da mucama com a sinhá-moça, do sinhozinho com o muleque" (p. 333) que foi assim traduzido: "la nourrice noire avec le petit blanc, de la femme de chambre de couleur avec sa jeune patronne, du jeune blanc avec le négrillon" (p. 319). Resultado em que se encontra apagado do léxico exatamente o campo semântico relativo ao polo casa-grande/senzala, obliterando-o praticamente na tradução francesa. E há que se ressaltar que "mucama" figura no glossário, inclusive com indicação de sua origem bantu, mukama, escrava. Ainda que, logo a seguir, numa enumeração de palavras de origem africana que foram incorporadas ao português do Brasil, figure a palavra muleque. Ela aparece inclusive numa pergunta, em que o autor brasileiro se interroga justamente sobre o emprego do termo: "Ou 'garoto', de preferência a 'muleque'?" (p. 334) como exemplo de integração de um léxico africano que não deixou de soar exótico no português do Brasil. E que assim ficou em francês: “Ou 'gamin' plutôt que muleque?” (p. 320). No entanto, duas palavras da sequência aparecem logo depois no texto traduzido; por que não as empregou quando eram tão fundamentais?

Como último exemplo podemos mostrar: iaiás (p. 339) traduzido por "femmes" (p. 339); mais convencional, impossivel.

\section{Distorsão de SENTIDo E Egú́vocos}

Vejamos o seguinte trecho: "A sifilização do Brasil resultou, ao que parece, dos primeiros encontros, alguns fortuitos, de praia, de europeus com indias" (p. 48). Sifilização é o ato ou efeito de sifilizar, indicando, portanto, de forma mais ativa, o processo de tomada do país pela doença. A tradução perde essa alusão que pretende imprimir mais força à disseminação da doença: "La syphilis au Brésil est venue, semble-t-il, [...]" (p. 87). Prossegue o autor dizendo que sobretudo portugueses e franceses ficavam para irem se "acamaradando com os indígenas; e que acabavam muitas vezes tomando gosto pela vida desregrada no meio de mulher fácil e à sombra de cajueiros e araçazeiros". O lapso do trecho produziu-se na tradução de "acamaradar-se" por "forniquer". Tendo o tradutor se equivocado provavelmente por conhecer mal o termo e talvez induzido pelo contexto.

No contexto da sexualidade, podemos às vezes pensar num pudor do tradutor. Comentando a tendência dos rapazes de familias de engenho por negras e mulatas, Freyre nos relata alguns casos extremos: por exemplo, o de um rapaz que, "para excitar-se diante da noiva branca precisou, nas primeiras noites de casado, de levar para a alcova a camisa úmida de suor, impregnada de budum, da escrava negra sua amante" (p. 284). O tradutor usou a expressão "consommer son mariage" (p. 262) para traduzir "excitar-se".

Outras vezes, traduz errado mesmo, provavelmente por desconhecimento exato da palavra: "de todas as marafonas da Bahia" (p. 249) virou "de tous les fripons de Bahia".

Ou mesmo "palhaço" por "paillasse" (uma espécie de colchão de palha), o que não faz o menor sentido (p. 417/376).

Pequenas informações são cortadas, aqui e ali: "Não só em relação ao beiju, mas a tudo quanto é comida indígena, a Amazônia é a área da cultura brasileira mais impregnada de influência cabocla" (p. 122). "Ce n'est pas seulement le beiju, c'est toute la nourriture qui est, en Amazonie, imprégnée d'influence indienne" (p. 134). A informação de que se trata da área de maior influência indígena 
perdeu-se. Mais grave ainda para o público francês que, evidentemente, domina menos o conhecimento das diferentes regiões brasileiras.

Numa citação de Nina Rodrigues, em que se procura mostrar o preconceito do referido intelectual, Freyre refere-se ao seu cargo, como a mostrar a importância de que se revestiria tal opinião: "escreveu o então professor da Faculdade de Medicina da Bahia” (p. 305). Tal informação foi sumariamente cortada da tradução (p. 286).

Algumas alterações são curiosas. Como é o caso do uso da palavra complexo que Freyre parece estar usando no seu sentido próprio: "Vários são os complexos característicos da moderna cultura brasileira de origem pura ou nitidamente ameríndia" (p. 161). Na tradução, encontramos: "nombreux traits" (p. 178). Será que Bastide julgou inadequado o uso do vocabulário técnico da psicanálise, que conhecia bem? Mas em outro momento, traduz literalemente: "O complexo brasileiro do bicho" (p. 131); "Le complexe brésilien de la Bête” (p. 143).

Por vezes, um adjetivo indiscreto desliza na tradução, carregando no sentido:

[...] a colonização da vasta terra americana afastou-se porém, das normas comerciais e burguesas do primeiro século do imperialismo para reviver os métodos de como que autocolonização aristocrática e agrária, aplicados no próprio Portugal ao território reconquistado aos mouros (p. 198).

O tradutor acentua a retomada, inserindo um adjetivo: "pour revenir aux vieilles méthodes" (p. 190, grifo meu).

Ou um comentário sobre a variação das culturas africanas: "Semelhante mapa nos alertaria, pelo puro alarme dos altos e baixos, contra o perigo das generalizações sobre os colonizadores africanos do Brasil" (p. 285) resultou na seguinte tradução: "contre le danger des généralisations trop hâtives des colonisateurs africains du Brésil” (p. 264, grifo meu). Alteração grave, pois o tradutor se pronuncia, toma partido, de tal forma o assunto o apaixona; entende-se, mas não se justifica em termos de técnica de tradução.

Nessa perspectiva, outras alterações na estrutura da frase podem revelar indiscretas tomadas de posição: "Foi o erro grave de Nina Rodrigues ao estudar a influência do africano no Brasil: o de não ter reconhecido no negro a condição absorvente de escravo" (p. 315) Bastide formula de forma muito mais enfática: "il n'a pas vu combien l'esclavage avait transformé le nègre" (p. 299). Será ainda o tradutor ou um leitor critico da obra quem fala?

Às vezes, podemos até nos perguntar sobre a eficiência da revisão. Ou será mesmo que o tradutor cortou frases? Falando sobre a influência do mouro sobre a civilização portuguesa, Freyre cita J. M. Esteves Pereira. A citação não vem entre aspas na tradução. É introduzida pela observação "mercê dos mouros e dos religiosos", repetindo-se depois da citação "mercê principalmente dos mouros". Essa segunda vez, excluindo a influência dos religiosos e ressaltando a dos mouros que não aparece na tradução.

Em outros momentos, os modalizadores desaparecem na tradução: "a própria oliveira parece ter se tornado melhor utilizada em Portugal depois da vinda dos mouros" e "a nomenclatura, proveniente do latim para as árvores - oliveira, olival, olivedo - de origem árabe no produto - azeitona, azeite - leva a pensar em um maior aproveitameno dessa espécie vegetal no periodo muçulmano" (p. 211, grifo meu) 
adquiriram um tom afirmativo: "s'est perfectionné" e "indiquent". Terá Bastide ficado amplamente convencido pela argumentação de Freyre?

Outro exemplo da omissão do modalizador: "Lowie parece-nos colocar a questão em seus verdadeiros termos" (p. 298, grifo meu). "Lowie pose la question dans ses vrais termes" (p. 278).

Em certos casos, a arbitrariedade das alterações não permite perceber bem se o tradutor não entendeu direito ou se achou sem importância e alterou o sentido:

Parecem-nos às vezes patranhas de frades - de frade colonial com letra bonita, sem assunto para seus exercícios de caligrafia e de gramática - as histórias que se contam da opulência e do luxo dos senhores baianos e pernambucanos nos séculos XVI e XVII (p. 260).

"Des racontars de moines - de moines coloniaux qui écrivaient bien, mais qui n'avaient rien à dire d'important, voilà ce que semblent être les histoires [...]" (p. 257). "O Brasil não se limitou a recolher da África a lama da gente preta que lhe fecundou os canaviais e os cafezais [...] que lhe completou a riqueza das manchas de massapê" (p. 308). "Le Brésil ne s'est pas limité à chercher en Afrique cette ----- boue noire qui a fécondé ses champs de cannes et de café [...] qui a completé ---- ses zonnes de massapê" (p. 290). Há, como se pode ver, duas omissões na tradução.

Algumas alterações parecem-me graves: "Comércio muito ativo e conduzido por Fulos e Mandingos: - em geral escravos” (p. 308). O tradutor alforriou os negros comerciantes: "en général ex-esclaves" (p. 291). E "africano récem-chegado" não pode virar "immigrant noir" sob pena de distorsão inclusive do sentido sociológico da palavra imigrante (p. 357/345).

\section{Análise de um Pegueno trecho}

No capítulo IV, há um trecho (p. 323-330) em que Gilberto Freyre discute um traço da cultura brasileira considerado de origem africana, o uso da feitiçaria e da magia. Trecho de tradução dificil por causa do léxico específico e do tom acentuadamente informal e oral.

O primeiro problema lexical é o campo semântico da feitiçaria, rico e variado; o léxico específico se desdobra de magia, feitiçaria, feitiço, mandinga, bruxaria a catimbozeiro, curandeiro, macumbeiro. Ora, se formos rigorosos e recorrermos ao dicionário, veremos que essas palavras não podem ser utilizadas como sinônimas. Magia é a arte ou ciência da bruxaria. Bruxaria, embora colocada como sinônimo de magia, merece ainda outra explicação, apresentada como magia negra. Trata-se da ação maléfica de bruxos ou de um acontecimento que, por falta de explicação lógica, se atribui à feitiçaria. Feitiçaria é o emprego de feitiços, que são os sortilégios, os malefícios dos bruxos. Catimbau é prática de feitiçaria ou baixo espiritismo, uma variação catimbó. Mandinga designa o indivíduo de raça negra cruzada com elementos etíope e berberes, tidos como mágicos e feiticeiros, daí a outra acepção de bruxaria. Mais importante ainda: há um critério na utilização das expressões no texto em português. A palavra magia é empregada exclusivamente no designativo da categoria: "magia sexual afro-brasileira". Na execução da magia, prefere-se a palavra feitiço ou mandinga, havendo denominações específicas como 
na expressão "café mandingueiro", "trata-se de um café com mandinga dentro", mas "antes filtro amoroso do que mandinga", nos explica o autor (p. 326).

Enquanto no texto francês, "magie" é utilizado de forma generalizada cobrindo magia sexual, feitiço e mandinga, inclusive "café mandingueiro" foi traduzido por "café magicien", "avec une magie dedans". Ora, sendo o sentido primeiro de "mandinga" um povo africano, existe a palavra "mandingues" ou "mandé" para designar esse povo, tornando possivel a utilização da palavra. Resulta, portanto, a tradução num texto muito empobrecido do ponto de vista semântico.

As sucessões lexicais têm exatamente a função de mostrar a riqueza do assunto: "De posse de qualquer dessas substâncias, o catimbozeiro, mandingueiro ou macumbeiro diz que 'abranda o coração' das pessoas mais esquivas” (p. 326). Em francês, traduziu-se assim: "sorcier, magicien ou féticheur" (p. 312), em nivel linguístico certamente menos popular. Uma linha abaixo, uma das designações é repetida: "Há catimbozeiros que confeccionam bonecos de cera ou de pano [...] Sobre essas calungas operam os mestres-carlos tudo quanto desejam...". Aqui o tradutor conservou a palavra "catimbozeiro", que figura no glossário; "calunga" (divindade secundária do culto banto; fetiche dessa divindade; boneco pequeno) torna-se simplesmente "poupées" e "mestres-carlos" sequer é retomado por um substantivo, mas substituído por um pronome indefinido "tout ce qu'on désire".

Nesse contexto de cuidados com o recém-nascido, em que se extravaza um afetivo coletivo, parece-me também uma perda a tradução de "mãe preta" (p. 326) por "domestique de couleur" (p. 312) por simplesmente "nourrice" (p. 340), num trecho em que Freyre mostra o lugar de honra muitas vezes ocupado pela mãe-preta (p. 352). Sobretudo porque, mais adiante, "mãe negra" será traduzido por "Mère-noire", com maiúscula (p. 318).

Como também "papão ou coca" por sorcier e croquemitaine. Papão e coca são assombrações de função bem clara: assustar criancinhas, o que é coberto só pela segunda expressão; talvez tivesse sido até mais interessante traduzir as duas por uma só, mas que preenchesse a mesma função. Essas especificações mal entendidas repercutem na compreensão da deliciosa afirmativa: "o século da luz elétrica que acabou com tanto assombrado bom" (p. 328), que virou "qui mit fin à tous ces fantômes", deixando de lado o trato afetivo e carinhoso da assombração.

Esse tom informal que faz as delícias de um leitor brasileiro foi outras vezes obliterado. Como neste outro pequeno exemplo, sem muita importância, mas igualmente significativo. Descrevendo monges das grandes ordens religiosas na vida portuguesa, Freyre conclui: "Os frades não foram em Portugal as simples montanhas de carne, asfixiantes e estéreis, em que alguns se deliciam em caricaturá-los" (p. 233). A alusão provável aos padres queirosianos que arrotam no confessionário e tão familiar à nossa formação literária neutralizou-se num "comme on les a caricaturés quelquefois".

\section{Estilo Pessoal de Freyre}

Mas as dificuldades de tradução não se atêm ao vocabulário regional. O estilo muito individual de Gilberto Freyre às vezes cria palavras. Há casos de advérbios fabricados: "Muito da inferioridade física do brasileiro, em geral atribuída toda à raça, ou vaga e muçulmanamente ao clima, deriva-se do mau aproveitamento dos nossos recursos naturais de nutrição" (p. 32). O trecho "ou vaga e 
muçulmanamente" foi cortado: "à la fatalité de la race ou du climat" (p. 65). O que se repetirá mais tarde com referência ao determinismo geográfico da formação mercantilista portuguesa: "tudo mulçumanamente determinado" (p. 241) reduziu-se a "du destin" (p. 236). E nesse contexto determinista, substituir "o mar não teria determinado sozinho a independência nem o comercialismo português” (p. 241) por "n’aurait pas créer" implica numa perda de sentido.

Há outro caso semelhante de advérbio fabricado: "Para os portugueses, o ideal teria sido não uma colônia de plantação, mas outra India com que israelitamente comerciassem em especiarias e pedras preciosas" (p. 24). Sem ousar criar o advérbio, o tradutor teve uma boa solução, substituindo por um aposto de portugueses: "ces Israélites de la mer" (p. 55).

Uma tendência a dar vivacidade ao texto por meio da ênfase - tão a gosto brasileiro e pouco do feitio cartesiano francês - fica de lado. Comentando o enfraquecimento físico do índio quando obrigado a incorporar-se ao sistema econômico do colonizador, diz Gilberto Freyre que nem o "tal inhame, nem os tais frutos da terra bastariam agora à alimentação do selvagem" (p. 158). "Tal" foi substituído por simples artigo (Inhame é dicionarizado: "igname", de origem espanhola).

Na página seguinte (p. 159), banzo, que designa exatamente - e tomamos a definição do dicionário - nostalgia mortal dos negros da África, se torna simplesmente "nostalgie". E, curiosamente, a palavra figura no glossário. A tradução generalizadora se torna mais problemática se atentarmos para o que se segue: a análise do suicídio do africano escravizado em terra estranha, por excesso de tristeza e saudades de sua pátria; nesse contexto, a palavra é fundamental e reveste-se de todo seu sentido específico. Curiosamente, ao voltar para seu país, Bastide voltou-se para os problemas de adaptação dos estudantes africanos na França; interesse talvez já despertado pelos seus estudos sobre o escravo africano no Brasil. Pensando nesse interesse do sociólogo, a redução de banzo a "nostalgie" chama a atenção para os seus procedimentos tradutórios.

Parece que, na maioria das vezes, ou escapou ao tradutor ou ele não quis reproduzir um tom oral - e por vezes irreverente - de Gilberto Freyre. Vejamos este trecho, em que expressa suas restrições à conduta de Portugal que, segundo ele, só busca imitar os países europeus de maior projeção:

Do século XVI até hoje, só tem feito aguçar-se no português a simulação de qualidades européias e imperiais, que possuiu ou encarnou por tão curto período. É um povo que vive de fazer de conta que é poderoso e importante. Que é supercivilizado à europeia. Que é grande potência colonial. [...] A Suíça que condense o seu leite e a Holanda que fabrique seus queijos. Portugal continua na ponta do pé, no esforço de aparecer entre as grandes potências européias (p. 192).

O uso do subjuntivo e o do possessivo, além de conferirem uma oralidade e uma informalidade à frase, são expressivos, como a assumir uma posição de desdém de Portugal em relação a pequenos países da Europa, paralelo a um esforço para distinguir-se no conjunto do continente. Na tradução, uma certa carga emocional da linguagem foi neutralizada: "Tandis que la Suisse fait du lait condensé et que la Hollande fabrique ses fromages, Le Portugal continue à se dresser sur la pointe des 
pieds, pour essayer de se faire voir, malgré sa petite taille, dans le groupe des grandes puissances" (p. 183). E, mais sério, o tradutor insere uma opinião não manifestada por Gilberto Freyre, que não aludia explicitamente ao tamanho físico de Portugal, mas a uma pretensão muito mais de ordem política e cultural.

Quanto ao ritmo da frase de Gilberto Freyre que, com muita frequência, quando quer chamar a atenção de forma enfática para algum aspecto do assunto analisado, enfileira frases sem verbos e sucessões de substantivos, o tradutor respeitou-o quase sempre e disso temos vários exemplos, facilmente recuperáveis.

Os trechos de estilo mais literário e até poético em geral estão cuidadosamente reproduzidos, esforçando-se o tradutor por conservar as imagens criadas:

Compreende-se o uso, em terras tão novas, de artigos refinados e de luxo. Por que não, se Pernambuco e a Bahia desde cedo tornaram-se pontos de nau que voltavam do Oriente, rangendo de tão carregadas de mercadorias de valor, arrastando-se pelo mar com vagares de mulher grávida; cheias de objetos finos que os portugueses vinham introduzindo por essa época na Europa aristocrática e burguesa? (p. 260)

[...] Pernambouc en effet et Bahia n'étaient-ils pas les escales de navire qui revenaient de l'Orient, gémissant sous le poids de tant de marchandises de valeur, la nef gonflée sur la mer comme un ventre de femme enceinte, lourd d'objets luxueux que les Portugais de l'époque introduisaient alors dans l'aristocratie et la bourgeoisie de l'Europe? (p. 258)

Um outro exemplo para reforçar esse procedimento que encontramos com frequência:

As mãos do senhor só servindo para desfiar o rosário no terço da Virgem; para pegar nas cartas de jogar; para tirar rapé das bocetas ou dos corrimboques; para agradar, apalpar, amolegar os peitos das negrinhas, das mulatas, das escravas bonitas de seus haréna (p. 429).

O tradutor não tergiversou e reproduziu escrupulosamente o uso variado das mãos dos senhores:

Les mains des maîtres ne servaient que pour égrener le chapelet, pour jouer aux cartes, pour tirer le tabac de la tabatière ou corrimboque, pour caresser, palper, pétrir les seins des négrillonnes, des mulâtresses, des jolies esclaves de leurs harems (p. 391).

Em geral, Bastide saiu-se bem na reprodução do estilo lírico - quando mais literário - de Gilberto Freyre; provavelmente porque seu próprio estilo de texto sociológico passeava com frequência pelo lirismo.

\section{BOAS SOLUÇÕES}

Apesar dos problemas apontados, a tradução conta, inúmeras vezes, com excelentes soluções lexicais: "De modo que o homem já não é o antigo mané- 
-gostoso de carne abrindo os braços ou deixando-os cair ao aperto do calor e do frio" (p. 14). Mané-gostoso é um personagem do bumba-meu-boi que aparece com pernas de pau cantando coplas. Uma das acepções é "fantoche", o que se confirma pela descrição que dele nos dá Freyre. Bastide traduziu por "polichinelle", personagem da comedia dell'arte e cuja segunda acepção em francês é igualmente fantoche.

Ou ainda: "E adeus! Está no papo do Quibundo" (p. 328); "Adieu! Il est dans le goître du Quibundo" (p. 314).

Um pouco antes, o tradutor ousou inclusive criar uma expressão: "bouf-tata". "No mato, o saci pererê, o caipora, o homem dos pés às avessas, o boi-tatá" (p. 328); "Dans la forêt, le saci-pererê, le caipora, l'homme aux pieds à l'envers, le boeuf-tata" (p. 314). O grifo é meu, pois a palavra inventada nem está em itálico.

Comentando a alimentação do brasileiro, Freyre a ela atribui muitas das "doenças do aparelho digestivo, comuns na época e por muito doutor caturra atribuidas aos "maus ares" (p. 36). Bastide traduziu "doutor caturra" por "docteurs moliéresques", o que conserva o tom irônico, casa-se bem com médico e, mais importante, será assim entendido pelo público francês, afeito às críticas de Molière aos médicos. No caso, duas traduções para a mesma palavra não me parece ter importância: mais à frente, o tradutor usará "un petit médicastre" (p. 363/353).

Moleque "leva pancadas" (p. 50) é traduzido por "attrape-coups" (p. 89). Tradução que nem sempre é seguida. Mais à frente a expressão é retomada, com referência, inclusive, ao fato de se tratar de uma retomada: "Ao muleque companheiro de brinquedo do menino branco e seu leva-pancadas, já nos referimos em capítulo anterior" (p. 336). Aqui a tradução é outra: "souffre-douleur" (p. 322). Essa segunda expressão existe em francês e significa exatamente uma pessoa ou animal que é vítima de maus-tratos; a primeira não, embora haja expressões formadas com "attrape" (attrape-tout; attrape-mouche). Apesar de as duas soluções serem interessantes, continuamos com o mesmo problema: o mesmo termo em português remete a dois diferentes na tradução. Tem-se a impressão que o tradutor, ao encontrar o termo existente em francês, não voltou para rever sua primeira tradução.

Não devemos deixar de lado uma solução muito acertada do tradutor. Lemos no texto de Freyre: “O 'dói' dos grandes tornou-se o 'dodói' dos meninos. Palavra muito mais dengosa” (p. 331). E o tradutor criou uma palavra nova "Le 'mal' des grands est devenue le 'mamal'; un mot tout sucré" (p. 317). Palavra que se insere no campo semântico do maternal "mamelle", seio, do latim "mamilla", diminutivo de "mamma", seio, captando e reproduzindo o acolhimento materno quando a criança está "dodói".

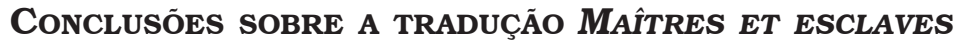

Não é minha intenção discutir teorias sobre tradução, porque não sou especialista nesse campo e tentativas nesse sentido correriam aqui o risco da superficialidade. Como expliquei na primeira nota, este texto inseria-se numa pesquisa mais ampla que seguia outra direção. Minha intenção era conhecer melhor o trabalho de Roger Bastide e sua relação com a cultura brasileira. Considerando-se que se trata da única tradução que levou a cabo, certamente isto é revelativo de seu especial interesse pela obra de Gilberto Freyre. E, mesmo que eu não 
adentre questões teóricas, pode-se considerar que a tradução é uma forma de leitura, como reforçam as observações que se seguem:

Pois o que aparece nitidamente no texto de Rilke é que a tradução é uma espécie de leitura-escrita, é escrita que testemunha uma leitura, leitura que se encarna em escrita. Toda tradução é leitura do texto original, e, no entanto, ela é também reeescrita; ato crítico e ato criador estão ligados (e de maneira talvez angustiante) no ato de traduzir, que não é mais um ou outro, mas os dois no mesmo grau (MASSON, 1996, p. 33).

Para tornar enfatizar as razões que certamente levaram Bastide a traduzir Gilberto Freyre, podemos recorrer ao testemunho do tradutor alemão de Os sertões, Berthold Zilly (1994), que declarou em entrevista à Folha de S.Paulo que "a melhor maneira de entender um livro dificil é traduzi-lo".

Deve-se levar em consideração que o texto de Casa-grande e Senzala não é de classificação simples e automática. Trata-se, claro, de um texto de sociologia. No entanto, sua linguagem não é exclusivamente técnica. A linguagem saborosa tem estilo muito próprio, particular; quase se pode ler o livro como um romance, uma saga dos senhores de engenho.

Antonio Candido (1976), no seu conhecido prefácio a Raizes do Brasil, compara a composição dos três livros fundamentais da sua formação, chamando atenção para o estilo livre do livro: Formação do Brasil contemporâneo, "que não disfarçava o labor da composição nem se preocupava com a beleza ou expressividade do estilo"; Raizes do Brasil, "livro curto, discreto, de poucas citações"; e Casa-grande e Senzala, de "intuito anticonvencional" e "composição libérrima".

Wilson Martins (1954, p. 338), em sua resenha da tradução, mostra um certo temor pela tradução do estilo freyriano:

Com efeito, o autor de Casa Grande e Senzala dispõe de um estilo pessoal e intransferível, sinuoso e cheio de malícia, rico de reminiscências e insinuações muitas vezes apenas perceptíveis, que se diria impossível a sua transposição para uma língua que se funda antes de mais nada na clareza lógica, na ordem direta e na afirmativa.

Não se pode deixar de lado essa resenha, único registro, de meu conhecimento, dessa tradução numa perspectiva brasileira. E Wilson Martins, como já dissemos, teve a ocasião de conversar sobre o assunto com Bastide, que comentou as dificuldades que encontrou ao traduzir a obra. Na sua opinião, entre duas tendências, uma centrada no texto outra, no receptor, o tradutor conseguiu um terceiro e equilibrado resultado:

Sem apagar os traços originais do autor traduzido e sem nada perder do seu "perfume estrangeiro" (na medida em que esse "perfume" suportava mudança tão radical de ambiente) o sr. Roger Bastide oferece-nos um admirável texto em francês de Casa-Grande e Senzala, apenas colorido, aqui e ali, pela construção romântica do sr. Gilberto Freyre (MARTINS, 1954, p. 338). 
Elogia muito a tradução e acha alguns termos regionais "verdadeiros achados" em francês, mas os que aponta - que não fica claro se estão entre esses achados - são traduções literais como jogo do bicho/jeu des bêtes; pé-de-moleque/ pied de négrillon.

Assim mesmo, cheio de dedos, tem ressalvas: sugere uma uniformização dos nomes próprios, ora traduzidos, ora não, conforme mostramos; e se pergunta se não seria melhor, em vez de traduzir engenho por moulin, conservar a palavra com uma nota de rodapé, corroborando vários exemplos que levantamos aqui.

Casa grande e Senzala era uma obra que gozava de certo prestígio junto à sociologia francesa: a "Notice biographique" que acompanha a tradução justifica a relevância dessa tradução: "En 1949, l'étude de son cuvre a été incluse en un cours de la Sorbonne".

Apesar da boa repercussão da obra, especificamente sobre a tradução, só encontrei dois comentários. Um de passagem, de Lucien Febvre, que no longo prefácio em que discorre sobre o Brasil e sobre o livro apenas faz referência à "traduction attentive de R. Bastide".

O texto a ser traduzido oferecia, portanto, duas dificuldades básicas: o assunto exigia um léxico regional de difícil correspondência na língua de chegada e um estilo muito particular, próximo do oral, necessitando um conhecimento aprofundado e de uma vivência do português.

Podemos, então, procurar situar a tradução de Roger Bastide considerando o texto e o público francês receptor da tradução. Temos um tradutor que conhece muito bem a área e é entusiasta da matéria traduzida. Podemos até dizer que seu trabalho mais significativo, sobre as religiões afro-brasileiras - e sem sombra de dúvida de grande peso e seriedade, produto de anos de pesquisa e reflexão - apresenta parentesco próximo com a obra traduzida.

Diríamos que Wilson Martins não deixa de ter razão ao afirmar que, entre o texto e seu receptor, Bastide conserva um equilíbrio. Mas não me parece que isso tenha sido resultado de reflexão teórica sobre o ato de traduzir ou mesmo uma posição assumida consciente e firmemente. Acho que poderíamos recorrer à posição do tradutor-leitor. Nesse caso, estamos diante de um tradutor que, obviamente, domina muitíssimo melhor a língua e a cultura de chegada, apesar de ser um competente estudioso do assunto tratado. E, diante de um texto carregado de linguagem e termos domésticos que povoam o universo afetivo de nossas infâncias, encontra-se em situação desconfortável, da qual, a meu ver, tinha consciência, mas não até as últimas consequências. Entrelaçaram-se a esse universo termos sociológicos que sofreram perdas significativas na passagem para o francês.

Trata-se de um tradutor entusiasta, apaixonado pelo Brasil e especialmente pelos assuntos tratados na obra traduzida, mas sem instrumental teórico de tradução, nem mesmo conhecimento sólido da linguagem regional, mas consciente da importância e da necessidade do trabalho que estava realizando.

Mesmo considerando que novas luzes se lançaram de 1952 até nossos dias sobre a tradução de obras brasileiras para o francês, podemos concluir que foi uma tradução cheia de problemas técnicos, realizada por um amador, impulsionado exclusivamente pela paixão pelo livro e pelas ideias do autor.

Como conclusão final, é preciso ressaltar a importância dessa tradução (1. ed. 1952; 2. ed. 1974) que não pode nem deve ser invalidada apesar de todas 
as ressalvas apresentadas. Mas ainda assim não é o texto ideal para que estudantes de sociologia na França se informem sobre a "formação da família brasileira sob o regime da economia patriarcal".

Essa conclusão me lembra uma observação de Paulo Rónai (1976, p. 76) a respeito das traduções de Proust no Brasil:

A primeira pergunta suplementar que aventamos - que impressão o original exerce sobre os conterrâneos do autor? - envolve a norma tantas vezes enunciada e que à primeira vista parece óbvia, de que a tradução deve dar aos leitores a idéia de a obra ter sido escrita em sua própria língua. Mas por mais perfeita que seja a interpretação, a impressão do leitor estrangeiro sempre será diferente da do leitor patrício do autor, e que lê a obra com o entendimento moldado por um background e uma experiência comuns. Por melhor que seja a tradução brasileira de A La Recherche du Temps perdu, executada por grandes escritores - ao leitor não familiarizado com o ambiente, a literatura, a história, a língua da França, parte das alusões, das indiretas, das ironias, das reticências há de escapar sempre. (É verdade que, se estivesse familiarizado com o conjunto cultural da França, leria Proust no original).

Será que um francês vai entender em todas as suas sutilezas e malícias o universo das alcovas das casas grandes, por onde perambulavam as sinhazinhas e suas mucamas, os ioiôs e seus muleques?

\section{LA TRADUCTION DE MAîtRES ET ESCLAVES EN FRANÇAIS}

Résumé: Le sociologue Roger Bastide, très attiré par l'oeuvre de Gilberto Freyre, a fait une traduction de Casa-grande e Senzala (Maîtres et esclaves), em 1952. Cet article a pour but d'examiner le résultat de ce travail et certains choix du traducteur français ayant affaire à la dure tâche de mettre dans sa langue ce texte si particulier qui a des traits si typiques de la culture brésilienne.

Mots clés: Traduction. Gilberto Freyre. Bastide

\section{REFERÊNCIAS}

BARTHES, R. Maîtres et esclaves. In: BARTHES, R. OEuvres complètes. Tome I, 1942-1961. Paris: Seuil, 2002.

BASTIDE, R. Carta aberta a Guerreiro Ramos. Anhembi, ano III, v. XII, n. 53, nov. 1953.

BASTIDE, R. Compte rendu de Ordem e Progresso. Cahiers Internationaux de Sociologie, v. 27, n. XXVII, p. 177-180, jul./dez. 1959.

CANDIDO, A. O significado de Raizes do Brasil. In: HOLANDA, S. B. de. Raízes do Brasil. Rio de Janeiro: J. Olympio, 1976. p. XIX.

FREYRE, G. Maîtres et esclaves. La formation de la société brésilienne. Paris: Gallimard, 1974. (Coll. La Croix du Sud, 1952). 
FREYRE, G. Casa-grande e Senzala. 28. ed. Rio de Janeiro: Record, 1992.

KIRSCH, G. F. Poética da tradução e tradução estética: Nove, novena na França e na Alemanha. 1998. Tese (Doutorado em Teoria Literária e Literatura Comparada)-Faculdade de Filosofia, Letras e Ciências Humanas, Universidade de São Paulo, São Paulo, 1998

LARANJEIRA, M. Crítica da tradução. A tradução: alvos e ferramentas. In: IV ENCONTRO NACIONAL DE TRADUTORES. São Paulo: USP, FFLCH/DLM/CET. São Paulo, 1 a 6 de abril 1990.

MARTINS, W. Casa-grande e Senzala em francês. Revista Anhembi, ano IV, v. 14, n. 41, p. 338-340, abr. 1954.

MASSON, J.-Y. Sur une traduction imaginaire de Sapho. La commotion des langues. Césure Revue de la Convention Psychanalytique, n. 11, p. 31-43, 1996. MESCHONNIC, H. Pour la poétique II. Épistémologie de l'écriture. Poétique de la traduction. Paris: Gallimard, 1973.

PAES, J. P. Tradução: a ponte necessária. São Paulo: Ática, 1990.

RÓNAI, P. A tradução vivida. Rio de Janeiro: Educação e Cultura, 1976.

ZILLY, B. Os sertões ganha tradução alemã. Entrevista à Folha de S.Paulo, São Paulo, 22 set. 1994. Caderno Mais!

Recebido em setembro de 2017.

Aprovado em setembro de 2017. 